\title{
Who is Visiting the Zagreb Zoo: Visitors' \\ Characteristics and Motivation
}

\author{
Martina Knežević \\ University of Zagreb, Croatian Studies, Psychology Department, Croatia \\ e-mail: martina.knezevich@gmail.com
}

\author{
I va Žučko
}

Zoological Garden of Zagreb, Croatia

e-mail:iva@zoo.hr

\author{
Maša Ljuština \\ Zoological Garden of Zagreb, Croatia \\ e-mail:mljustenator@gmail.com
}

\begin{abstract}
In order to attract visitors despite a growing competition in entertainment and recreation industry, the service quality in zoos needs to satisfy the ever increasing demands and expectations of the modern visitor. The aim of this study was to examine the socio-demographic characteristics of the Zagreb Zoo visitors, explore their motivation and satisfaction with offered services. A self-administered questionnaire was designed, which included demographic data, frequency of visits, accompanying persons, average spending, motivation and ratings of services and programs. The majority of the Zagreb Zoo visitors were family groups who spend more money on tickets than on gifts and souvenirs. As top motivators for their visit, participants listed children and watching animals, while education was very low on the list. The Zoo staff, facilities and entertainment programs were very highly rated. This was the first ever study of the Zagreb Zoo visitors. These data can be used to help the Zagreb Zoo understand the visitors' demands and their perception of the zoo. They can also provide a basis for actions to improve weaknesses and enhance the service quality, thereby increasing the enjoyment of future visitors.
\end{abstract}

Key words: Zagreb Zoo, visitor studies, motivation, service quality, animal welfare. 


\section{Introduction}

The Zagreb Zoo is situated in more than 200 years old Maksimir Park, almost in the city centre. This makes it one of the city's favourite places for relaxation and entertainment. It was founded in 1925, and at first was situated on the Swan Island with only 5 animals - 3 foxes and 2 owls (Milčec et al., 2012). Just one year after its founding, due to numerous donations from wealthy city dwellers, the Zagreb Zoo territory was expanded to land surface. Today, on 5.5 hectares of land surface ( 7 hectares together with the lake) visitors can see 338 species and around 6000 individual animals from almost every continent - mammals, birds, reptiles, amphibians, fishes and invertebrates (Zagreb Zoo records, 2014). When looking at the numbers for the last 40 years, the Zagreb Zoo never had less than 215000 visitors per year (Croatian Bureau of Statistics, 2014). Major data peaks (600 000 visitors per year) are correlated with very important projects the Zagreb Zoo finished, like opening new pavilions or exhibits. It seems that city dwellers and tourists followed the development and progress of the Zagreb Zoo and were happy to give their support in form of their visit.

Entertainment has traditionally been perceived as one of the primary roles of the zoos. However, entertainment industry is constantly growing enabling individuals to choose from various attraction, making it very hard for the zoos to provide competing and satisfactory experiences (Lee, 2015). People generally enjoy and appreciate nature and wildlife in their day-to-day lives, and museums, zoos, aquariums and other similar institutions, in addition to entertainment, now offer recreational and educational opportunities to their visitors (Ballantyne, Packer and Hughes, 2008; Kamolpattana et al., 2015; Kidd and Kidd, 1997; Ma et al., 2012; Marino et al., 2010; Randler, Höllwarth and Schaal, 2007). In modern zoos there has been a shift in emphasis from entertainment toward conservation of species under threat of extinction. They are promoted as places where visitors can learn about animals and how to contribute to the survival of endangered species, but also as a place for social interaction, relaxation or simple outdoor experience (Anderson, Kelling and Maple, 2008; Anderson et al., 2003; Yilmaz, Mumcu and Ozbilen, 2010). Who are modern zoo visitors and what motivates them to spend their free time visiting animals in zoos?

Most zoo visitors studies have explored visitors' motivation (Ballantyne et al., 2008; Connell, 2004; Sickler and Fraser, 2009), behaviour (Anderson et al., 2008; Anderson, Maple and Bloomsmith, 2010; Hosey, 2000; McPhee et al., 1998; Yilmaz et al., 2010), and attitudes (Ballantyne et al., 2008; Marino et al., 2010; Webber and Hill, 2014). They showed that zoos in general give people a chance to observe wildlife that they may otherwise never see (Carr and Cohen, 2011; Randler et al., 2007). Visitors believe zoos play an important role in conservation, animal care and education, and that they experience a stronger connection to nature as a result of their visit (Anderson et al., 2003; Carr and Cohen, 2011; Falk et al., 2007). During a three year period, Falk et al. (2007) studied more than 5500 visitors in 12 zoos and aquariums using various quantitative and qualitative methods, like questionnaires, interviews and tracking studies. They found that zoos and aquariums can enhance visitors' knowledge and understandings of wildlife and conservation, as well as their con- 
nection to nature, prompting individuals to reconsider their role in environmental problems and conservation actions. That is in line with the goal of the modern naturalistic zoo exhibits to improve animal welfare standards through environmental enrichment and naturalistic features in order to reduce their behavioural and physiological problems, like stereotypic behaviours or obesity and nutrient deficiencies (Anderson et al., 2008; Carr and Cohen, 2011; Marino et al., 2010).

Many people visit zoos to share experiences with their children, strengthen social ties with family and friends, and even find psychological comfort by enjoying the nature and interacting with animals (Lee, 2015; Sakagami and Ohta, 2010). Others point out recreation and enjoyment as high motivators for their visit (Sickler and Fraser, 2009). Lee (2015) conducted a survey at six public zoos in Korea, investigating the demands and satisfaction levels of zoo visitors. Convenience and safety in observing animals were rated as very important, and children were a particularly significant motivators for zoo visits. Animals' welfare and information-seeking were identified as the key determinants effecting overall satisfaction. Contrary to the original image of zoos as primarily sites of entertainment, increasing interest in welfare of the zoo animals pressure zoos to maintain high standards of service and provide a variety of educational programs (Carr and Cohen, 2011; Lee, 2015).

Visitors also report appreciation of the aesthetic and rear qualities of plants, admiration of gardens' scenery and surroundings, as well as pleasure of being outdoors as one of the key aspects of their enjoyment during zoo visitation (Ballantyne et al., 2008). Spending time surrounded by nature provides peaceful and tranquil environment for leisure consumption. Research has shown that visiting zoos and parks gives an opportunity to escape everyday life, with benefits for emotional, psychological, and even spiritual values, enabling recreation in a quiet and enjoyable surroundings (Connell, 2004). Several researchers have investigated the physical design of exhibits (Cowan, Darwent and Riva, 1999; Jeggo, Young and Darwent, 2001; Jensen, 2007; Kelling, Gaalema and Kelling, 2014; Yilmaz et al., 2010), and available services (Lee, 2015). For example, Jensen (2007) stressed the importance of the "hygiene" factors, such as eating, parking and toilet facilities, because they can have a negative effect on visitors' overall perception and therefore satisfaction.

As a member of European and World Association of Zoos and Aquariums and in accordance with modern zoos around the world, the Zagreb Zoo takes special care in designing and building new animal enclosures that resemble animals' natural habitat, conducts enrichment and other programs in order to achieve maximum animal welfare (Hosey, Melfi and Pankhurst, 2009). It also organizes various educational programs, some specialized for school groups, and others for everyday visitors, offering information about the animals and the nature itself. Besides giving experience to visitors through getting to know many wild animal species, the Zagreb Zoo has more than 127 marked species of plants and very rich cultural and historical heritage (Milčec et al., 2012). Through fostering an appreciation of biodiversity, it is becoming an important venue for environmental education. As such, it has the potential to promote the importance of plants and conservation, and to communicate the significance of preserving not only endangered animal species, but also plants for 
the future well-being of the planet (Ballantyne et al., 2008; Jordaan and du Plessis, 2011; Luebke et al., 2015).

In order to keep operating and to ensure economic viability, zoos need to attract visitors. To be able to attract visitors despite the increasing competition in entertainment and recreation industry, the service quality of the zoo needs to satisfy the demands and expectation of the modern visitor. The aim of this study was to investigate socio-demographic characteristics of the Zagreb Zoo visitors and to explore their motivation and attitudes towards the zoo, in order to obtain more information regarding the demands and requirements for visitors' satisfaction and to draw implications for possible improvements. This information can be used for improving existing exhibits and designing new ones more effectively, as well as visitor programs and facilities. It is up to the zoo exhibit designers to balance between the welfare of the animals, zoo staff management requirements, and the needs of the visitors (Hosey et al., 2009; Hosey, 2000). This is a very hard task, because the needs and wishes of visitors are often not complementary with the needs of animals. The results of this study will provide information for establishing strategies to improve zoo experience and satisfaction and to enhance service quality, increasing thereby enjoyment of future visitors.

\section{Method}

\subsection{Participants}

A total of 3052 visitors completed the questionnaire (64\% females), ranging from 18 to 83 years of age $(M=36.32 ; S D=10.72)$. The most common age group participating in the study were 25 - 39 year olds (56\%), followed by 40 - 64 year olds (28\%) and $18-24(14 \%)$, while only $2 \%$ were 65 or older. More details about participants are outlined in the Results and discussion section.

\subsection{Procedure}

Trained research assistants were stationed at the main entrance, where they approached adult visitors aged 18 years and older. Only one volunteering adult per group was asked to participate. They were informed that the Zagreb Zoo is conducting a research in order to better understand the visitors, and that the data will be used to ensure the highest quality service. Also, it was highlighted that their participation in the study was completely voluntary, including the right to quit at any stage if they did not feel comfortable continuing the process. If agreed, each participant received a coded ticket with the time of entrance which they returned to the researchers, marking the time of exit. Upon returning the coded thicket, participants received the questionnaire which they completed before exiting. Each questionnaire was coded with identification number in advance, thus ensuring the confidentiality of the data. Data were collected in autumn, spring and summer of 2010 and 2011. 
During that time, we randomly selected one week every month, and collected data every day during that week, including weekdays, weekends and holiday periods. Each participant was rewarded with a poster of the one of the zoo animals upon completion of the questionnaire.

\subsection{The questionnaire}

A self-administered questionnaire was designed for the purposes of this research, divided into four sections: (1) demographic data, frequency of visits and accompanying persons, (2) average spending (tickets, Zoo café, gifts and souvenirs, other) (3) motivation, and (4) ratings of services and programs (scale 1 - lowest, 5 - highest, 0 - cannot evaluate). It also contained information about proposed changes for the Zoo and the amount of time spent viewing the exhibit. Average time for the completion of the questionnaire was around 10 minutes.

\subsection{Statistical analyses}

We calculated frequencies, means, standard deviations, t-tests and ANOVAs for group differences, with Bonferroni post-hoc test.

\section{Results and Discussion}

\subsection{Demographic data, frequency of visits and average spending}

Out of 3052 visitors who participated in this study, 47\% reported having a high school degree, $38 \%$ graduate and 14\% undergraduate degree, while $1 \%$ had less than high school degree. The majority of participants (64\%) were Zagreb residents, with $27 \%$ from other parts of Croatia, and 9\% from other countries. Given the large proportion of participants from Zagreb, it is not surprising that only $12 \%$ were first time visitors, and out of $88 \%$ of repeated visitors, $25 \%$ visits the Zoo several times a year. Most participants came as a family group (72\%), and $72 \%$ came with children. Participants also came as couples (17\%), friends (9\%) or on their own (2\%). They spent approximately two hours $(M=114.87$ minutes; $S D=42.81)$ on average in the Zoo.

Visitors spend most money on tickets (Table 1), and least on gifts and souvenirs, as well as on other offerings in the Zoo, like buying ice-creams. Visitors with children spend significantly more money in total, most on tickets, Zoo café and gifts and souvenirs, compared to visitors without children. There were no sex, but we found age differences in spending. In Zoo café, 18 - 24 year olds spend less money than 25 - 39 $(p<.01)$ and $40-64(p<.01)$ year olds, which was also reflected in total amount of spent money, showing that $18-24$ year olds spend less money in total than $25-39$ $(p<.05)$ and $40-64(p<.01)$ year olds. Visitors aged 64 or more did not differ in average spending in Zoo café from other age groups $(p>.05)$. 
Table 1.

Average spending on various Zoo facilities during the visit.

\begin{tabular}{|c|c|c|c|c|c|c|}
\hline & & $\begin{array}{c}\text { All visitors } \\
N=3052 \\
M(S D)\end{array}$ & $\begin{array}{l}\text { With children } \\
\qquad \begin{array}{c}N=2183 \\
M(S D) \\
a\end{array}\end{array}$ & $\begin{array}{l}\text { Without children } \\
\qquad \begin{array}{c}N=869 \\
M(S D) \\
b\end{array}\end{array}$ & $t_{a b}$ & $d f$ \\
\hline Tickets & & $64.75(46.02)$ & $67.35(47.86)$ & $58.22(40.33)$ & $4.96^{*}$ & 3044 \\
\hline Zoo café & & $18.36(30.52)$ & $20.26(31.99)$ & $13.59(25.87)$ & $5.48^{*}$ & 3046 \\
\hline Gifts and souvenirs & & $7.54(31.76)$ & $8.83(35.71)$ & $4.32(18.05)$ & $3.55^{*}$ & 3045 \\
\hline Other & & $6.02(24.51)$ & $6.54(23.48)$ & $4.72(26.88)$ & 1.84 & 3046 \\
\hline \multirow[t]{4}{*}{ Total } & & $96.42(79.56)$ & $102.62(84.12)$ & $80.84(64.21)$ & $6.87^{*}$ & 3050 \\
\hline & & & Males & Females & & \\
\hline & & & $N=1096$ & $N=1951$ & & \\
\hline & & & $M(S D)$ & $M(S D)$ & $t$ & $d f$ \\
\hline Tickets & & & $64.42(41.63)$ & $64.91(48.34)$ & .28 & 3040 \\
\hline Zoo café & & & $19.20(32.95)$ & $17.92(29.09)$ & 1.11 & 3042 \\
\hline Gifts and souvenirs & & & 7.67 (36.28) & $7.49(28.95)$ & .16 & 3041 \\
\hline Other & & & $5.77(25.78)$ & $6.15(23.76)$ & .41 & 3042 \\
\hline \multirow[t]{4}{*}{ Total } & & & $96.71(84.48)$ & $96.32(76.74)$ & .13 & 3045 \\
\hline & age $18-24$ & age $25-39$ & age $40-64$ & age $64>$ & & \\
\hline & $N=422$ & $N=1702$ & $N=837$ & $N=68$ & & \\
\hline & $M(S D)$ & $M(S D)$ & $M(S D)$ & $M(S D)$ & $F$ & $d f$ \\
\hline Tickets & $61.37(71.01)$ & $65.02(39.05)$ & $66.28(43.88)$ & $54.81(33.12)$ & 2.13 & 3,3019 \\
\hline Zoo café & $12.41(32.31)$ & $19.51(30.19)$ & $19.00(30.23)$ & $18.30(25.21)$ & $6.31^{*}$ & 3,3021 \\
\hline Gifts and souvenirs & $7.71(63.25)$ & $6.98(21.37)$ & $8.37(25.18)$ & $9.25(32.14)$ & .43 & 3,3020 \\
\hline Other & $3.81(12.15)$ & $6.88(29.63)$ & $5.67(17.71)$ & $2.73(8.36)$ & 2.29 & 3,3021 \\
\hline Total & $85.06(128.75)$ & $98.24(68.23)$ & $98.96(68.68)$ & $83.40(62.49)$ & $4.06^{*}$ & 3,3025 \\
\hline
\end{tabular}

Note: values are in Croatian kunas; ${ }^{*} p<.01$.

The profile of the Zagreb Zoo visitors is similar to visitors from other zoological gardens (Lee, 2014; Randler et al., 2007), showing that zoo visitors are likely to be highly educated mid adults, married with children, who come in family groups.

There are several ways in which the Zoo could attract more tourists. Zoo gardens are attractive to many people, not just those with a specific interest of seeing animals, but also those who are looking for a pleasant day out or a way to spend time with the loved ones. The Zagreb Zoo offers all this and more, and should be presented as such, for example in stronger cooperation with Zagreb Tourist Board or other marketing and tourism organizations. Evidence from a number of major European cities suggest that individual zoos, like Berlin Zoo or Rotterdam Zoo, are indeed major urban attractions (Catibog-Sinha, 2008; Ryan and Saward, 2010). Therefore, strengthening collaboration with different tourist agencies could help in establishing the Zagreb Zoo as a tourist attraction brand. Regarding marketing strategies, age is a significant factor to consider. Connell (2004) found that visitors between 40 and 60 years of age are more likely than other age groups to be motivated to visit the gar- 
den by a leaflet or a flyer, those between 18 and 39 are more likely to use web sites, while those over 60 are more likely to make use of word-of-mouth. The Zagreb Zoo should take this into consideration while choosing how to present its offers. Broadening marketing strategies to social media, e.g. Facebook, Twitter, LinkedIn, could help in reaching younger generations prone to using technology in everyday life, making information about the Zagreb Zoo activities more available and possible increase the frequency of their visits.

Attracting elderly population may be another factor to consider. The Zagreb Zoo is very suitable for those seeking a relaxed and peaceful environment, and research shows this is one of the highest motivators for elderly visitors (Ballantyne et al., 2008; Dzhambov and Dimitrova, 2014; Jensen, 2007.; Lee, 2015). Therefore, visitations could be encouraged by highlighting peaceful and relaxing aspects of the zoo, with activities like music concerts, art and craft lessons etc., while first-time elderly visitors may appreciate more discovery activities like themed quizzes, maps or guided walks. Season tickets or loyalty programs through which visitors could gain reward points for frequent visitations during the season could warrant their return.

The fact that visitors spend least amount of money on gifts and souvenirs can be changed with changes in offer or souvenir shop improvements. For example, it seems that orienting the main offer towards families with children is the way to go. Since visitors rarely come on their own, activities that encourage and enhance social interaction, e.g. jigsaw puzzles shaped like specific animal or animal playing cards, may be effective for all age groups and extend the popularity of the Zoo souvenir shop. It could also offer practical items for the visit, such as rainwear, sunglasses or sunscreen, as well as toys, puzzles, games, unique gifts and souvenirs depicting the Zoo. All this should be presented in spacious and colourful shop, ensuring comfortable browsing and shopping of the offered items. Considering that the souvenir shop is currently located in a very small, confined space, before any changes in the offer, increasing and modernizing the space of the shop should be a top priority. Research shows that shopping satisfaction is not derived only from acquiring goods, but shopping environment itself becomes a part of the shopper's experience influencing subsequent shopping behaviours (Yüksel, 2007).

\subsection{Identifying motivation for zoo visit}

Motivation is usually defined as an internal state that activates, directs and maintains one's behaviour (Ryan and Deci, 2000). Zoo visitors are not a homogenous group, and their motives for visit can range from recreation to education or social interaction with friends and family. A number of studies revealed that children accounted for a very large proportion of zoo visitors (Mason, 2000; Wagoner and Jensen, 2010). Others have categorized the zoo mainly as a place of relaxation and personal enjoyment (Car and Cohen, 2011). Jordaan and du Plessis (2014) showed that some people visit the zoo in order to have a self-directed zoo experience (e.g., relaxation, recreation), while other visit the zoo to promote the welfare of others (e.g., family togetherness). Motivational research broadly distinguishes between two types of motivation: 
(1) intrinsic, which refers to doing something because it is inwardly rewarding or enjoyable, and (2) extrinsic, which refers to doing something that results in external (outside of the individual) rewards (Ryan and Deci, 2000). What motivates the Zagreb Zoo visitors? In order to answer this questions, we asked visitors to write down what motivated them to come to the Zagreb Zoo. Their answers are shown in Figure 1.

Most of the Zagreb Zoo visitors listed animals, zoo and children as their motivation. Others listed several motivators for their visit, including children, watching animals, enjoying nature and spending quality time. According to the motivators that the Zagreb Zoo visitors listed, they can be classified as primarily intrinsic (doing an activity for its inherent satisfaction), and our results are in line with most contemporary zoo visitor research (Jordaan and du Plessis, 2014; Ballantyne et al., 2008; Falk, Heimlich, and Bronnenkant, 2010). Studies have shown that people are more likely to continue with their behaviour and invest more time in it if they are intrinsically motivated (Morgan and Hodgkinson, 1999; Falk, et al., 2010) and thus such activities should be promoted.

Figure 1.

Frequency of visitors answers to the question "What motivated you to come and see the animals in the Zagreb Zoo?"

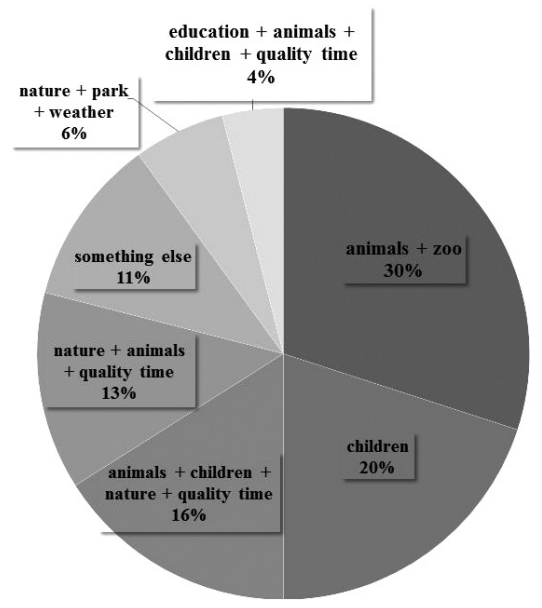

The fact that many visitors are accompanied by children suggests that topics and activities that encourage family sharing and conversations are likely to be attractive. For example, seeing animals up close, perhaps in walk-through enclosures, and talking to their caretakers, setting up corners with sketch books and crayons for observing animals and sketching the observation, organizing birthday parties or weekend workshops in the zoo, is something that any member of the family could enjoy (Anderson et al., 2003; Ballantyne et al., 2008; Connell, 2004; Davey, 2007). These activities could increase the popularity of the zoo among families with children, but also ensure their return. The Zagreb Zoo has some entertainment programs, like birthday parties or eco academy program, mostly during weekends or in connection to celebrating important nature conservation dates (Milčec et al., 2012). Advertising and promotion of these family sharing activities should be upgraded and enhanced so the visitors become aware of what is offered in the Zagreb Zoo. 
Interestingly, only $5 \%$ listed education as one of the motivators for visiting the Zoo. In this respect, the Zagreb Zoo visitors are similar to botanic gardens visitors (Ballantyne et al., 2008; Connell, 2004) and other modern-day zoo and aquarium visitors (Jordaan and du Plessis, 2011; Ryan and Saward, 2010), determining zoos as primarily places of family-oriented trips, and emphasizing enjoyment in animals, nature, and spending quality time with children, friends and family, rather than learning. Even though education is not very high on the list of motivators for visiting the Zagreb Zoo, modern zoos should be places where visitors learn about animals and should demonstrate how an individual can contribute to the survival of endangered species (Carr and Cohen, 2011; Lee, 2015). If the Zagreb Zoo is to introduce more educational activities, they need to give careful consideration to how these are planned and promoted. Since activities with a strong educational emphasis are unlikely to appeal, preparing visitors for learning experience by, for example, using inspirational panels or pamphlets to prompt their interest in conservation and animal care or giving suggestions how to "get the most" out of their visit may prompt spontaneous, accidental learning and increase interest for learning more about both individual animals and/or species (McGregor and Gribble, 2015; Thwaites, 2014). Hands on sessions that make connections between visitors and animals, such as holding, petting or feeding, are also likely to be popular, enabling each visitor to form emotional connection with a specific animal and evoke concern about the importance of protecting wildlife (Wagner et al., 2009). It should also be tested if conservation oriented education conducted by zoo staff increases knowledge and understanding or change in behaviour of visitors in any way that would benefit species conservation or conservation of nature in general.

Since not everyone can be intrinsically motivated for any particular activity (Ryan and Deci, 2000) whether for doing it for the first time or repeating the activity, introducing extrinsic motivators as additional element could make a successful marketing strategy. Classic examples of very successful extrinsic motivators are rewards. When used well, they can even enhance intrinsic motivation (Cameron, Banko and Pierce, 2001). For example, zoos could offer gift certificates or credits for future participation in educational or entertainment programs. In this way, the zoo could promote those activities in which visitors are not engaged at all or are engaged to a small proportion. Such external motivators could help leveraging motivation toward repeated visit, however one should be careful since offering excessive rewards can actually lead to a decrease in intrinsic motivation (Cameron, et al., 2001).

\subsection{Ratings of Zoo facilities and programs}

Visitors rated the Zagreb Zoo facilities with high grades (Table 2). They gave the highest rates for "the keeper's talk" program, informative panels and friendliness of the staff, and lowest for the number of animal species and services of the Zoo café. Unfortunately, because of the small size of the Zagreb Zoo, number of animals is not easy to change. This also emphasizes the importance of education on animal welfare, which is closely linked to number of animals that can be held in good conditions in the zoo (Davey, 2007; Hosey, 2000; Randler et al., 2007). 
Table 2.

Average ratings of Zoo facilities and programs

\begin{tabular}{lc}
\hline & All visitors \\
& $M(S D)$ \\
\hline Zoo facilities & \\
Friendliness of the staff & $4.41(.92)$ \\
Services of the Zoo café & $3.98(1.03)$ \\
Appearance of animal enclosures & $4.03(.88)$ \\
Number of animal species & $3.82(.90)$ \\
Signs/directions & $4.34(.95)$ \\
Informative panels & $4.56(.76)$ \\
Zoo programs & \\
Lake boat-ride $(N=175)$ & $4.45(.99)$ \\
Photo-safari $(N=140)$ & $4.39(1.01)$ \\
Keeper's talk $(N=363)$ & $4.59(.82)$ \\
\hline
\end{tabular}

Two questions from the questionnaire were asked in order to assess overall satisfaction with the Zagreb Zoo: "Is there something you would change in Zagreb Zoo?" and "Would you recommend visiting Zagreb Zoo". Visitors' answers are presented in Figure 2.

Figure 2.

Percentage of participants who would (not) recommend some changes/visit to the Zagreb Zoo.

Is there something you would change in Zagreb Zoo?

Would you recommend visiting Zagreb Zoo?
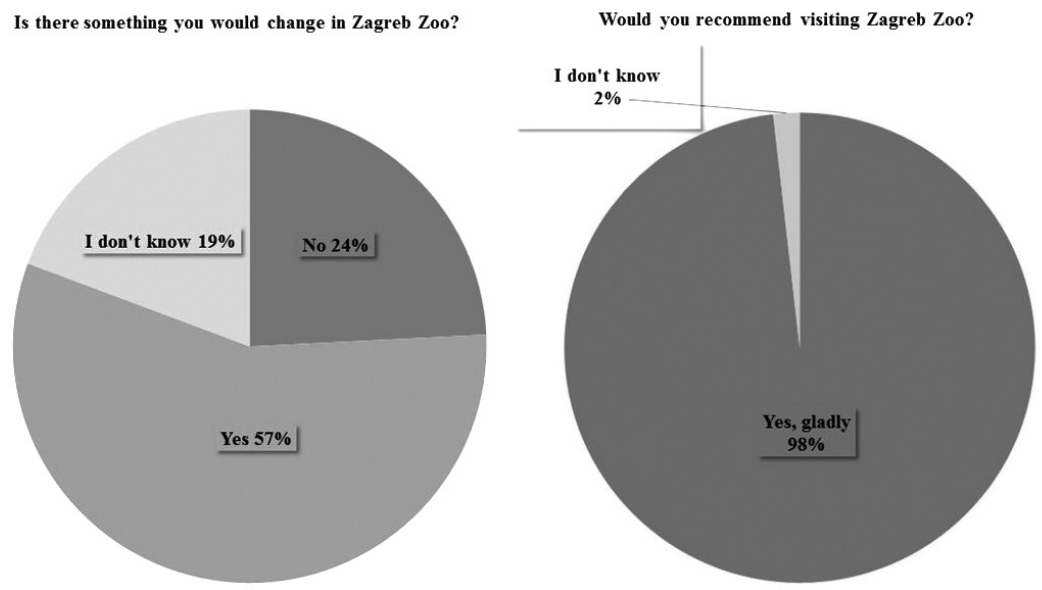

Out of visitors who suggested changes in the Zoo, 25\% did not know quite what would they change, and 7\% where undecided. Interestingly, only one visitor suggested expanding offers in the Zoo shop.

What could change is the fact that only a small proportion of visitors used available programs: $6 \%$ lake boat-ride, $5 \%$ photo-safari, $12 \%$ keeper's talk, but rated them with high grades. Out of these, $70 \%$ of lake boat-ride, $64 \%$ of photo-safari and $77 \%$ of 
keeper's talk consumers were visitors with children. Zoo staff could promote their programs more and try to engage more visitors in them. For example, some zoos produce printed leaflets, guidebooks, maps and brochures to inform visitors about the species on show, but also to promote ongoing events, shopping possibilities or programs (Anderson et al., 2010; Luebke et al., 2015; Sickler and Fraser, 2009). They could also try to investigate why visitors do not engage in certain programs in order to develop best approaches consistent with actual visitors' needs. For example, Carr and Cohen (2011) investigated the contents of websites of 54 zoos throughout the world in order to assess the general public image that they are currently portraying. They showed that in order to respond to the market demands, zoos nowadays offer entertainment opportunities beyond simply coming and seeing the animals (Carr and Cohen, 2011). Besides involving more visitors in available programs, zoo staff could also try to change amount of time spent in the zoo, which is less than two hours, and for that purpose, visitors' answers to the question where they stopped and spent most of their time in the Zagreb Zoo could be used. For example, since majority stopped to spend some time watching sea lion feeding, this could mean that more public feedings could be of interest and prolong their stay in the zoo. Also, since many say that they spent more time watching African lions, monkeys and apes, providing environmental enrichment in their exhibits and making animals more active could have the same effect. Especially since some studies showed that visitor interest is generally greater when animals are active (Margulis, Hoyos, and Anderson, 2003) and enriched exhibits influence activity of animals (Hosey et al., 2009).

One third $33 \%$ ) of the visitors that would change something in the zoo would like zoo to acquire new animals. As mentioned before, it is not always possible to acquire new animals, especially since it is to some extent in collision with $20 \%$ of visitors who suggest improvement of animal housing. Zoo visitors clearly identify that some animals need better and bigger enclosures (such as large carnivores, especially bears and cats). On the other hand, most of the animals that people want the zoo to acquire are the animals that need large, spacious exhibits (such as elephants or giraffe). Modern public zoos have made substantial efforts to move from old-fashioned barred cages, and improve animal housing through more naturalistic exhibits. Since dissatisfaction with the animal housing is strongly associated with a reason for not visiting zoos (Lee, 2015), it seems that further efforts should be made to educate visitors of the limits in acquiring some of the wanted animals. A number of studies have shown that zoo environment influences visitors' perception of the animals (Finlay, James and Maple, 1988; Hosey, 2000; McPhee et al., 1998; Reade and Waran, 1996; Webber and Hill, 2014; Yilmaz et al., 2010).

This is the first ever study of the Zagreb Zoo visitors. It provided some interesting and so far not known insights into the motives and interests of a large sample of visitors, which can be used to help the Zagreb Zoo to understand visitors' demands and their perception of the zoo services and performance. It can also provide a basis for actions to improve the weaknesses and enhance the strengths for better service quality. Using some advanced analysis techniques in zoo visitor studies could help provide greater insights into visitor needs and for managerial decision-making. 
One of the limitations of this study is the generalization of the results, since this research was undertaken during a defined short-time period, avoiding special events and celebrations in the Zagreb Zoo. For that reason, the results may not be generalized across a wide range of zoos, but the data can be used as a complement information about visitors' characteristics and demands, as a source for benchmarking and comparison, as well as organizational considerations about how to enhance visitors' satisfaction.

\section{Conclusion}

To attract visitors, modern zoos must be both entertaining and educational, without jeopardizing the animals' welfare. Investigating visitors' demographics, motivation and satisfaction, this study found that the majority of the Zagreb Zoo visitors are family groups, specifically parents with children, who spend more money on tickets, than on gifts and souvenirs. As top motivators for their visit, participants listed viewing animals, visiting the zoo as a whole, and their children, while education was very low on the list. Zoo staff, facilities and entertainment programs were rated with very high grades. It seems that expectations of the Zagreb Zoo visitors are more oriented on entertainment and family bonding than education. Therefore, the Zagreb Zoo needs to continue its role as a place for recreation and family bonding, but also to focus attention to more diverse educational programs that will suit the needs and requirements of the visitors, and most importantly, invest more in marketing strategies. Further research is required in order to, for example, measure the impact of the zoo experience on visitors' conservation knowledge, attitudes and behaviours or to understand how and what visitors learn during their visitations.

\section{References}

1. Anderson, U. S.; Kelling, A. S. and Maple, T. L. (2008). Twenty-five years of Zoo Biology: a publication analysis. Zoo Biology, 27 (6): 444-457. Doi: 10.1002/ zoo. 20177.

2. Anderson, U. S.; Kelling, A. S.; Pressley-Keough, R.; Bloomsmith, M. A.; Maple, T. L. (2003). Enhancing the zoo visitor's experience by public animal training and oral interpretation at an otter exhibit. Environment and Behavior, 35 (6): 826-841. Doi: 10.1177/0013916503254746.

3. Anderson, U. S.; Maple, T. L. and Bloomsmith, M. A. (2010). Factors facilitating research: a survey of zoo and aquarium professionals. Zoo Biology, 29 (6): 663675. Doi: 10.1002/zoo.20306.

4. Ballantyne, R.; Packer, J. and Hughes, K. (2008). Environmental awareness, interests and motives of botanic gardens visitors: Implications for interpretive practice. Tourism Management, 29 (3): 439-444. Doi: 10.1016/j.tourman.2007.05.006.

5. Carr, N. and Cohen, S. (2011). The Public Face of Zoos: Images of Entertainment, Education and Conservation. Anthrozoos, 24 (2): 175-189. Doi: 10.2752/1 $75303711 X 12998632257620$. 
6. Cameron, J.; Banko, K. M. and Pierce, W. D. (2001). Pervasive negative effects of rewards on intrinsic motivation: the myth continues. The Behavior Analyst, 24 (1): 1-44.

7. Catibog-Sinha, C. (2008). Zoo Tourism: Biodiversity Conservation Through Tourism. Journal of Ecotourism, 7 (2\&3): 155-173. Doi: 10.2167/joe-0229.0.

8. Connell, J. (2004). The purest of human pleasures: the characteristics and motivations of garden visitors in Great Britain. Tourism Management, 25 (2): 229247. Doi: 10.1016/j.tourman.2003.09.021.

9. Cowan, K., Darwent, M. and Riva, C. (1999). The design of first impressions, a new multi-species enclosure at Jersey Zoo. Dodo, 35: 8-25.

10. Croatian Bureau of Statistics (2014). Statistical Yearbook of the Republic of Croatia 2014. Zagreb: Croatian Bureau of Statistics.

11. Davey, G. (2007). Visitors' effects on the welfare of animals in the zoo: a review. Journal of Applied Animal Wealfare Science, 10 (2): 169-183. Doi: 10.1080/10888700701313595.

12. Dzhambov, A. M. and Dimitrova, D. D. (2014). Elderly visitors of an urban park, health anxiety and individual awareness of nature experiences. Urban Forestry E Urban Greening, 13 (4): 806-813. Doi: 10.1016/j.ufug.2014.05.006.

13. Falk, J. H.; Heimlich, J. and Bronnenkant, K. (2010) Using identity-related visit motivations as a tool for understanding adult zoo and aquarium visitor's meaning-making. Curator: The Museum Journal, 51 (1): 55-79. Doi: 10.1111/j.21516952.2008.tb00294.x.

14. Falk, J. H.; Reinhard, E. M.; Vernon, C. L.; Bronnenkant, K.; Deans, N. L.; Heimlich, J. E. (2007). Why Zoos \& Aquariums Matter: Assessing the Impact of a Visit. Association of Zoos \& Aquariums. Silver Spring, MD.

15. Finlay, T.; James, L. R. and Maple, T. L. (1988). Peoples Perceptions of Animals the Influence of Zoo Environment. Environment and Behavior, 20 (4): 508-528. Doi: $10.1177 / 0013916588204008$.

16. Hosey, G.; Melfi, V. and Pankhurst, S. (2009). Zoo Animals: Behaviour, Management, and Welfare (2nd ed.). New York: Oxford University Press.

17. Hosey, G. R. (2000). Zoo animals and their human audiences: What is the visitor effect? Animal Welfare, 9 (4): 343-357.

18. Jeggo, D.; Young, H. G. and Darwent, M. (2001). The design and construction of the Madagascar teal aviary at Jersey Zoo. Dodo, 37: 50-59.

19. Jensen, J. M. (2007). An empirical investigation of the relationships between hygiene factors, motivators, satisfaction, and response among visitors to zoos and aquaria. Tourism Review International, 11 (3): 307-316. Doi: $10.3727 / 154427207783948784$.

20. Jordaan, Y. and du Plessis, G. M. (2011). Motivators to visit the National Zoological Gardens of South Africa. African Journal of Hospitality, Tourism and Leisure, 3 (1): 1-15.

21. Kamolpattana, S.; Chen, G.; Sonchaeng, P.; Wilkinson, C.; Willey, N.; Bultitude, K. (2015). Thai visitors' expectations and experiences of explainer interaction within a science museum context. Public Understanding of Science, 24 (1): 6985. Doi: $10.1177 / 0963662514525560$. 
22. Kelling, N. J.; Gaalema, D. E. and Kelling, A. S. (2014). A Modified Operational Sequence Methodology for Zoo Exhibit Design and Renovation: Conceptualizing Animals, Staff, and Visitors as Interdependent Coworkers. Zoo Biology, 33 (4): 336-348. Doi: 10.1002/zoo.21134.

23. Kidd, A. H. and Kidd, R. M. (1997). Aquarium visitors' perceptions and attitudes toward the importance of marine biodiversity. Psychological Reports, 81 (3): 1083-1088. Doi: 10.2466/pr0.1997.81.3f.1083.

24. Lee, H. S. (2015). Measurement of visitors' satisfaction with public zoos in Korea using importance-performance analysis. Tourism Management, 47: 251-260. Doi: 10.1016/j.tourman.2014.10.006.

25. Luebke, J. F.; Clayton, S.; Kelly, L. A.; Grajal, A. (2015). Global climate change attitudes and perceptions among south American zoo visitors. Zoo Biology, 34 (4): 385-393. Doi: 10.1002/zoo.21224.

26. Ma, J.; Liao, I.; Kwan-Liu, M.; Frazier, J. (2012). Living Liquid: Design and Evaluation of an Exploratory Visualization Tool for Museum Visitors. IEEE Transactions on Visualization and Computer Graphics, 18 (12): 2799-2808. Doi: 10.1109/TVCG.2012.244.

27. Margulis, S. W.; Hoyos, C. and Anderson, M. (2003). Effect of felid activity on zoo visitor interest. Zoo Biology, 22 (6): 587-599. Doi: 10.1002/zoo.10115.

28. Marino, L.; Lilienfeld, S. O.; Malamud, R.; Nobis, N.; Broglio, R. (2010). Do Zoos and Aquariums Promote Attitude Change in Visitors? A Critical Evaluation of the American Zoo and Aquarium Study. Society \& Animals, 18 (2): 126-138. Doi: 10.1163/156853010X491980.

29. Mason, P. (2000) Zoo Tourism: The Need for More Research. Journal of Sustainable Tourism, 8 (4): 333-339. Doi: 10.1080/09669580008667368.

30. McGregor, H. R. and Gribble, P. L. (2015). Changes in visual and sensory-motor resting-state functional connectivity support motor learning by observing. Journal of Neurophysiology, 114 (1): 677-688. Doi: 10.1152/jn.00286.2015.

31. McPhee, M. E.; Foster, J. S.; Sevenich, M.; Saunders, C. D. (1998). Public perceptions of behavioral enrichment: Assumptions gone awry. Zoo Biology, 17 (6): 525-534. Doi: 10.1002/(Sici)1098-2361(1998)17:6<525::Aid-Zoo6>3.0.Co;2-W.

32. Milčec, M.; Filipović, M.; Vitez, G.; Kušan, I.; Hitrec, H.; Pavličić, P.; Maljković, D. (2012). Divlja djeca Maksimira: knjiga o zagrebačkome Zoološkom vrtu. Zagreb: Ustanova Zoološki vrt grada Zagreba.

33. Morgan, J. M. and Hodgkinson, M. (1999) The motivation and social orientation of visitors attending a contemporary zoological park. Environment and Behavior, 31 (2): 227-239. Doi: 10.1177/00139169921972074.

34. Randler, C.; Höllwarth, A. and Schaal, S. (2007). Urban Park Visitors and Their Knowledge of Animal Species. Anthrozoos, 20 (1): 65-75. Doi: 10.2752/089279307780216696.

35. Reade, L. S. and Waran, N. K. (1996). The modern zoo: How do people perceive zoo animals? Applied animal behaviour science, 47 (1-2): 109-118. Doi: 10.1016/0168-1591(95)01014-9.

36. Ryan, R. M. and Deci, E. L. (2000). Intrinsic and Extrinsic Motivations: Classic Definitiions and New Directions. Contemporary Educational Psychology, 25: 5467. Doi: 10.1006/ceps.1999.1020. 
37. Ryan, C. and Saward, J. (2010). The Zoo as Ecotourism Attraction - Visitor Reactions, Perceptions and Management Implications: The Case of Hamilton Zoo, New Zealand. Journal of Sustainable Tourism, 12 (3): 245-266. Doi: $10.1080 / 09669580408667236$.

38. Sakagami, T. and Ohta, M. (2010). The effect of visiting zoos on human health and quality of life. Animal Science Journal, 81 (1): 129-134. Doi: 10.1111/j.17400929.2009.00714.x.

39. Sickler, J. and Fraser, J. (2009). Enjoyment in zoos. Leisure Studies, 28 (3): 313331. Doi: 10.1080/02614360903046649.

40. Thwaites, P. (2014). Maximizing learning from written output. ELT Journal, 68 (2): 135-144. Doi: 10.1093/elt/cct098.

41. Wagner, K.; Chessler, M.; York, P.; Raynor, J. (2009). Development and Implementation of an Evaluation Strategy for Measuring Conservation Outcomes. Zoo Biology, 28 (5): 473-487. Doi: 10.1002/zoo.20270.

42. Wagoner, B. and Jensen, E. (2010). Science learning at the Zoo: evaluating children's developing understanding of animals and their habitats. Psychology and society, 3 (1): 65-76.

43. Webber, A. D., and Hill, C. M. (2014). Using Participatory Risk Mapping (PRM) to Identify and Understand People's Perceptions of Crop Loss to Animals in Uganda. Plos One, 9 (7): e102912. Doi: 10.1371/journal.pone.0102912.

44. Yilmaz, S.; Mumcu, S. and Ozbilen, A. (2010). Effects of spatial differences on visitor perceptions at zoo exhibits. Scientific Research and Essays, 5 (16): 23272340.

45. Yüksel, A. (2007.). Tourist shopping habitat: Effects of emotions, shopping value and behvaiors. Tourism Management, 28 (1): 58-69. Doi: 10.1016/j.tourman.2005.07.017.

46. Zagreb Zoo records (2014). Inventory list of species for 2014 by Zoological Information Management System. Zagreb: Zoological Garden of Zagreb. 
Martina Knežević

Sveučilište u Zagrebu, Hrvatski studiji, Odjel za psihologiju, Hrvatska

e-mail: martina.knezevich@gmail.com

\section{Iva Žučko}

Zoološki vrt grada Zagreba, Hrvatska

e-mail:iva@zoo.hr

Maša Ljuština

Zoološki vrt grada Zagreba, Hrvatska

e-mail:mljustenator@gmail.com

\section{Tko su posjetitelji zagrebačkog Zoološkog vrta: karakteristike i motivacija posjetitelja}

\section{Sažetak}

Kako bi mogli privući posjetitelje unatoč sve većoj konkurenciji u industriji zabave i rekreacije, kvaliteta usluga zooloških vrtova mora zadovoljiti zahtjeve i očekivanja suvremenog posjetitelja. Cilj ovog istraživanja bio je ispitati sociodemografske karakteristike posjetitelja Zoološkog vrta grada Zagreba te istražiti njihovu motivaciju i zadovoljstvo ponuđenim uslugama. Za potrebe istraživanja izrađen je upitnik koji je uključivao demografske podatke, učestalost posjeta, osobe u pratnji, prosječnu potrošnju, motivaciju i ocjene usluga i programa. Većina posjetitelja zagrebačkog zoološkog vrta obiteljske su grupe, koje troše više novca na ulaznice nego na poklone i suvenire. Sudionici su naveli djecu i promatranje životinja kao najvažnije motivatore za posjet, dok je edukacija vrlo rijetko na popisu. Osoblje zoološkog vrta kao i postojeći zabavni programi ocjenjeni su vrlo visokim ocjenama, iako su zabavni programi rijetko posjećeni. Ovo je prvo ikad provedeno istraživanje posjetitelja Zoološkog vrta grada Zagreba, u kojem su uz dosad nepoznate informacije o posjetiteljima, ponuđene i mogućnosti za poboljšanje ponude s obzirom na iskazane interese i u skladu s praksom drugih zooloških vrtova. Podaci se mogu iskoristiti za razumijevanje potreba posjetitelja te njihove trenutne percepcije zoološkog vrta, a mogu poslužiti i kao osnova za poboljšanje kvalitete usluga, što će u konačnici povećati broj posjetitelja kao i njihovo zadovoljstvo.

Ključne riječi: Zoološki vrt grada Zagreba, istraživanje posjetitelja, motivacija, kvaliteta usluge, dobrobit životinja. 